\title{
20. DIAGENESIS OF CALCAREOUS NANNOFOSSILS
}

\author{
R. Rezak and M.E. Henry, Department of Oceanography, Texas A\&M University, College Station, Texas
}

\section{INTRODUCTION}

Six samples were examined using petrographic and scanning electron microscopes in an attempt to observe differences in the nannofossil assemblages in the alternating hard and soft layers of Site 296, Core 21, Section 3. The samples were from the following depths: $39-41$ $\mathrm{cm}$, hard clay-rich nannofossil ooze; $54-56 \mathrm{~cm}$, soft clayrich nannofossil ooze; $74-75 \mathrm{~cm}$, hard clay-rich nannofossil ooze; 100-101 cm, soft clay-rich nannofossil ooze; $128-129 \mathrm{~cm}$, hard clay-rich nannofossil ooze; 140-141 $\mathrm{cm}$, soft clay-rich nannofossil ooze.

A cursory examination of the calcareous nannofossil assemblages in these samples showed them to be very similar and to contain the following species: Coccolithus pelagicus, Cyclococcolithina leptopora, Discoaster brouweri, $D$. variabilis, $D$. challengeri, $D$. berggrenii, $D$. surculus, $D$. calcaris, $D$. pentaradiatus, and $D$. bollii. The stratigraphic ranges of the discoasters present in the sampled intervals indicate an upper Miocene age. The assemblages are in general similar to those found in the Discoaster neohamatus Zone, except that $D$. neohamatus was not observed, and Discoaster berggrenii is abundant.

\section{RESULTS}

According to A.H. Bouma (personal communication), the hard layers are not bounded by sharp contacts but rather are gradational with the super- and subjacent soft layers. This is indicative of cementation within the sediment column rather than at the sedimentwater interface. Present water depth at Site 296 is 2920 meters which is above the calcium carbonate compensation depth and would preclude a large amount of dissolution during sedimentation. However, the samples show a variation in amount of dissolution between the hard and soft layers. Coccoliths appear to be more susceptible to dissolution than discoasters, and in the hard layers the coccoliths show a considerable increase in the effects of dissolution. Dissolution effects were also noted in the soft layers, but to a much lesser degree. Nonbiological calcium carbonate is more abundant in the hard layers and appears as crystalline aggregates in the scanning electron micrographs (Plate 1, Figures 1, 3 ). In addition, many of the discoasters from the hard layers show secondary deposits of calcium carbonate. This is not common in the soft layers.

The average porosity for this section is $66.8 \%$ which is quite high. Information is not available on the permeabilities of the two sediment types. However, there probably is not a great difference between the two. Core 21, Section 3 occurs within subunit 1E (92-206 m); however, the distinction to Subunit IF (206-282 m) is based on color changes and the presence of radiolarians as a lithologic component in Subunit 1F. Otherwise, the hard (chalk-like) soft (ooze-like) interbedding continues to the base of Subunit 1F $(282 \mathrm{~m})$. The pore-water chemistry (White, this volume) shows: a downward increase in $\mathrm{Ca}^{++}$, and $\mathrm{Sr}$ through Subunits $1 \mathrm{E}$ and $1 \mathrm{~F}$, and a general decrease in $\mathrm{Mg}^{++}$through the two subunits. These are very broad-scale geochemical results, and it would be interesting to know what specific differences exist in the pore-water chemistry of the hard and soft layers.

One is tempted to suggest that the cementation is occurring at present and that eventually the soft layers will also be cemented. However, this requires a chemical stratification of the pore waters with alternating zones of saturation and undersaturation. This seems unlikely considering the high average porosity of the sediment. An alternative explanation might involve varying rates of sedimentation with the cementation occurring at a given distance below the sediment-water interface. This would effectively remove the sediment from the zone of cementation as it became buried beneath successive floods of sediment.

The latter hypothesis seems more probable as there are many examples of hard and soft layers in Mesozoic chalks. Some of these are occurrences of hard grounds with sharp upper boundaries, but many have gradational boundaries, both above and below the cemented intervals. Actually, the presence of hard grounds in some of these older chalks supports the idea of intermittent floods of sediment separated by periods of no sedimentation. 


\section{PLATE 1}

Scanning electron micrographs of typical assemblages from Leg 31, Hole 296, Core 21, Section 3.

All photo scales are $10 \mu$

Figure 1 Hard layer, sample depth $74-75 \mathrm{~cm}$. Interval showing nonbiological crystallites.

Figure 2 Soft layer, sample depth $100-101 \mathrm{~cm}$.

Figure 3 Hard layer, sample depth $128-129 \mathrm{~cm}$. Note overall similarity to Figure 1 in terms of debris.

Figure 4 Soft layer, sample depth $140-141 \mathrm{~cm}$. 
PLATE 1
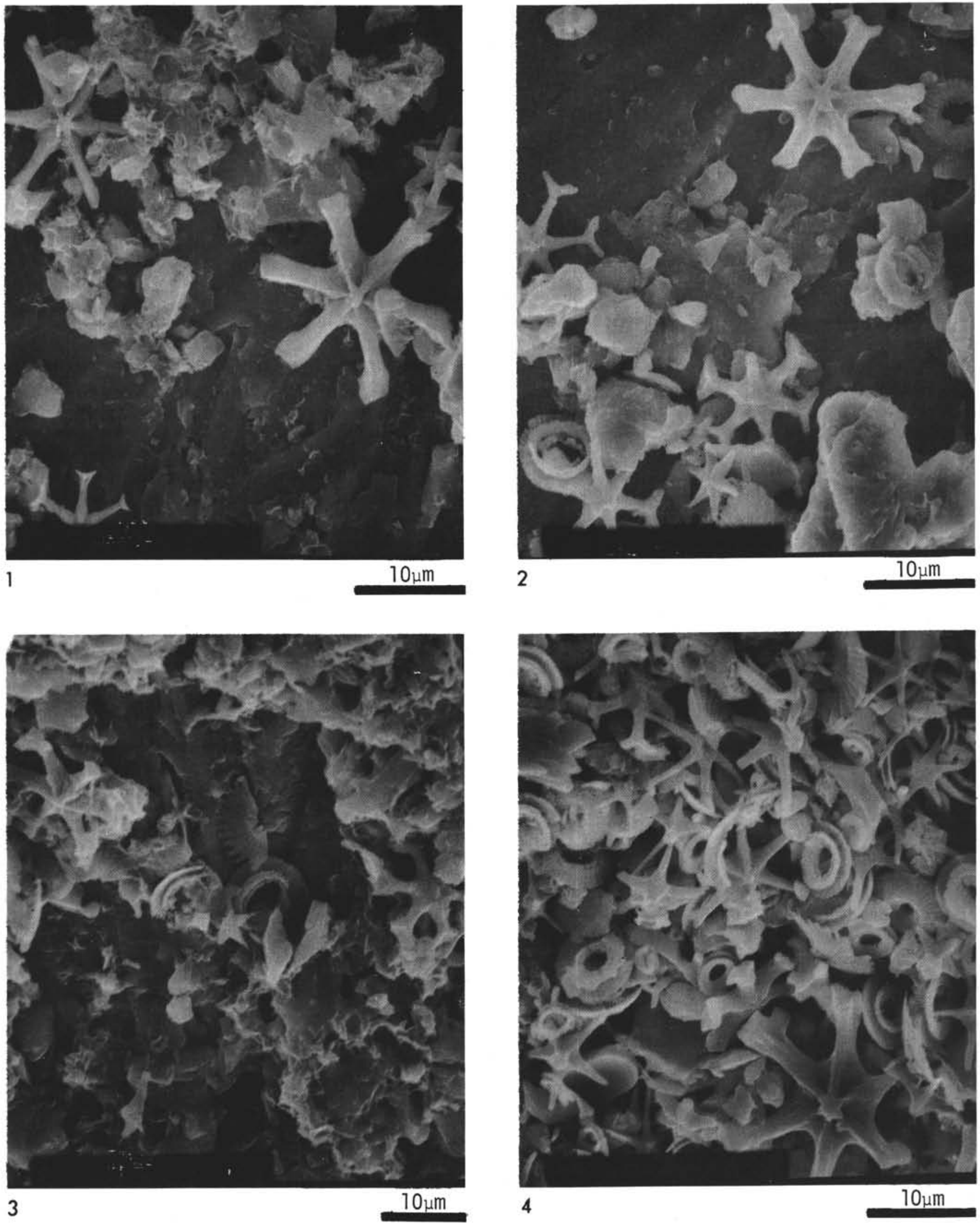